\title{
Direct and indirect coupling of primary production and diel nitrate dynamics in a subtropical spring-fed river
}

\author{
James B. Heffernan a,b,1,* and Matthew J. Cohen ${ }^{a}$ \\ a School of Forest Resources and Conservation, University of Florida, Gainesville, Florida \\ b Water Institute, University of Florida, Gainesville, Florida
}

\begin{abstract}
We used high-frequency in situ measurements of nitrate $\left(\mathrm{NO}_{3}^{-}\right)$and dissolved oxygen (DO) from the springfed Ichetucknee River, Florida, to derive multiple independent estimates of assimilatory nitrogen $(\mathrm{N})$ demand, and to evaluate the short-term dependence of heterotrophic assimilation and dissimilation (e.g., denitrification) on gross primary productivity (GPP). Autotrophic $\mathrm{N}$ assimilation estimates derived from diel DO variability and GPP stoichiometry agreed closely with estimates based on integration of diel variation in $\mathrm{NO}_{3}^{-}$concentration, although the correspondence of these metrics depended on the method used to estimate $\mathrm{NO}_{3}^{-}$baselines. In addition, day-to-day changes in nocturnal $\mathrm{NO}_{3}^{-}$concentration maxima were strongly negatively correlated with day-to-day changes in GPP. Diel temperature variation in the Ichetucknee River indicated that this pattern could not be explained by hydrologic dispersion, while relationships between $\mathrm{N}$ assimilation and $\mathrm{O}_{2}$ production at hourly intervals indicated minimal physiological lags. The estimated magnitude of heterotrophic assimilation was small, indicating that the relationship between changes in GPP and changes in nocturnal $\mathrm{NO}_{3}^{-}$maxima reflects sensitivity of denitrification to variation in exudation of labile organic matter by primary producers. We estimate that $\sim 35 \%$ of denitrification may be fueled by the previous day's photosynthesis; this result is consistent with the broader hypothesis that the magnitude of autochthonous production in aquatic systems influences the fate of $\mathrm{N}$ via both direct and indirect mechanisms.
\end{abstract}

Ecosystem nutrient cycling and export are closely tied to the metabolic activity of primary producers via both direct and indirect mechanisms (Knops et al. 2002). Most directly, assimilation of nutrients by autotrophs is an important pathway of nutrient transformation in terrestrial, freshwater, and marine ecosystems (Johnson et al. 2006; Roberts and Mulholland 2007; Templer et al. 2008). However, even in systems where bulk organic matter (OM) is abundant, heterotrophic metabolism and nutrient transformations (both assimilatory and dissimilatory) are often tightly coupled to recent photosynthetic activity or other pathways of OM input (Hamilton and Frank 2001; Vance and Chapin 2001; Picek et al. 2007). This relationship is thought to reflect the greater lability of fresh detritus and exudates vis-à-vis older $\mathrm{OM}$ pools that persist precisely because of their low nutrient content and structural complexity (Cebrian and Duarte 1995).

Spatial and temporal variation in sources of organic matter to streams and rivers can have important consequences for both assimilatory and dissimilatory pathways of $\mathrm{N}$ removal. Metabolic processes in small forested streams are dominated by inputs from terrestrial systems in the form of seasonal litter pulses and delivery of largely recalcitrant dissolved organic matter (DOM). The magnitude and quality of such inputs, and resulting variation in heterotrophic respiration, influence both heterotrophic assimilation (Hoellein et al. 2007; Roberts and Mulholland 2007) and denitrification (Mulholland et al. 2009) in small

\footnotetext{
* Corresponding author: jheffer@fiu.edu

${ }^{1}$ Present address: Department of Biological Sciences, Florida International University, Miami, Florida
}

streams. In higher-light environments such as arid and semiarid landscapes, and in larger channels, autochthonous production is a more important, and often the primary, source of organic matter. When and where autochthonous production is high, both assimilation (Roberts and Mulholland 2007; Hall et al. 2009) and denitrification (Holmes et al. 1996; Mulholland et al. 2009) may be coupled to productivity in space and time.

Studies of nutrient cycling in lotic ecosystems are strongly biased toward small streams, largely due to methodological constraints. In smaller streams, nutrient spiraling approaches allow relatively precise, methodologically consistent, and, in the case of isotopic tracers, process-specific estimates of biotic and hydrologic fluxes. Practical constraints have limited the application of these methods to larger fluvial systems (but see Dodds et al. 2008; Tank et al. 2008). Open-channel methods allow direct whole-system measurement of denitrification in large rivers (Laursen and Seitzinger 2002; McCutchan et al. 2003), but existing methods for estimating autotrophic and heterotrophic assimilation in streams and rivers rely on application of stoichiometric and growth efficiency coefficients to metabolic rates. These indirect methods have generally been applied only to smaller streams (Hall and Tank 2003; Webster et al. 2003), where estimates generally agree with assimilation measurements from isotopic tracers and nutrient enrichments, albeit with varying precision (Fellows et al. 2006; Mulholland et al. 2006; Valett et al. 2008). In large rivers, the lack of independent whole-system measures of assimilation has limited assessment of metabolism-based estimates. As a result, estimates of $\mathrm{N}$ removal in large rivers are based on mass balance, and they are therefore unable to resolve the 
mechanisms responsible for $\mathrm{N}$ removal, let alone address their interactions. Limited understanding of $\mathrm{N}$ dynamics in large rivers is a key constraint on efforts to model those processes at the scale of whole river networks (Wollheim et al. 2006; Tank et al. 2008). Moreover, even in small streams, understanding of interactions between ecosystem metabolism and nutrient cycling is largely based on crosssystem comparison of single measurements; few studies have addressed the temporal dynamics of such interactions (but see Hoellein et al. 2007; Roberts and Mulholland 2007; von Schiller et al. 2008), and none to our knowledge in large rivers.

Diel variation in nutrient concentrations is common in aquatic ecosystems, particularly during times of high primary productivity (Grimm 1987; Roberts and Mulholland 2007). Less-structured fine-scale variation in nutrient concentrations, likely due to water management, has also been observed (Pellerin et al. 2009). Recently developed in situ nutrient sensors allow description of fine-scale patterns of variation for extended durations, and they can potentially be used to quantify autotrophic assimilation. In Monterey Bay, California, integrated diel variation of $\mathrm{NO}_{3}^{-}$concentration $\left(\left[\mathrm{NO}_{3}^{-}\right]\right)$was strongly correlated with, and accounted for $70 \%$ of the $\mathrm{N}$ demand attributable to, monthly new production (Johnson et al. 2006). In this study, we use time series of $\left[\mathrm{NO}_{3}^{-}\right]$to estimate assimilatory $\mathrm{N}$ demand in a spring-fed river (Ichetucknee River, Columbia County, Florida), and we compare these estimates with contemporaneous metabolic rates at hourly to seasonal timescales. Because nutrient inputs from contributing springs are temporally stable and spatially discrete (Heffernan et al. 2010), we are able to infer dynamics of assimilatory and dissimilatory $\mathrm{N}$ removal by heterotrophs at daily scales, and we are able to evaluate, at the whole-ecosystem scale, the relationship between variation in these processes and day-today changes in primary production.

\section{Methods}

Site description-The Ichetucknee River, located in southern Columbia County, Florida, is a tributary to the Santa Fe River and part of the Suwannee River drainage. The river is entirely fed by six large springs that emerge from the karstic Floridan Aquifer within its upper $2 \mathrm{~km}$. U.S. Geological Survey (USGS) gauges measure discharge in these major springs and at U.S. Highway 27, which acts as the southern boundary of Ichetucknee Springs State Park, and is $\sim 5 \mathrm{~km}$ downstream of the Ichetucknee headspring. Total discharge from the six gauged springs averages $9.9 \mathrm{~m}^{3} \mathrm{~s}^{-1}$, about $11 \%$ greater than river discharge $\left(8.9 \mathrm{~m}^{3} \mathrm{~s}^{-1}\right)$. Like other springs that drain the Floridan Aquifer, the springs of the Ichetucknee River have extremely stable discharge, temperature, and solute chemistry (Odum 1957; Heffernan et al. 2010). Among the major springs, $\left[\mathrm{NO}_{3}^{-}\right]$ranges from 200 to $900 \mu \mathrm{g} \mathrm{NO}_{3}-\mathrm{N} \mathrm{L}^{-1}$. Dissolved organic $\mathrm{N}(\mathrm{DON})$ and ammonium $\left(\mathrm{NH}_{4}^{+}\right)$in springs discharge are typically below detection limits, and downstream accrual is minimal (Heffernan et al. 2010). Concentrations of soluble reactive phosphorus (SRP), which accounts for
$>95 \%$ of total phosphorus, range from 20 to $60 \mu \mathrm{g} \mathrm{P}$ $\mathrm{L}^{-1}$. DO in springs ranges from $\sim 4 \mathrm{mg} \mathrm{O}_{2} \mathrm{~L}^{-1}$ in the upstream Ichetucknee headspring to $0.5 \mathrm{mg} \mathrm{O}_{2} \mathrm{~L}^{-1}$ in Mill Pond Spring. The Ichetucknee River is $10-25 \mathrm{~m}$ wide and 1-2 m deep through most of its $8-\mathrm{km}$ length, with the exception of the 1-km-long "rice marsh" section $(\sim 100 \mathrm{~m}$ wide) that begins about $1 \mathrm{~km}$ from the headspring. The total riverbed area in the study area is $\sim 0.154 \mathrm{~km}^{2}$, and it supports dense beds of submerged macrophytes, particularly Sagittaria kurziana and Vallesnaria americana. Emergent and floating macrophytes occur along channel margins and in shallow lateral portions of the rice marsh, but they contribute negligibly to total biomass (Kurz et al. 2004). Filamentous cyanophytes (e.g., Lyngbya spp.) and xanthophytes (e.g., Vaucheria spp.) are also present as epiphytes on vascular plants, and as benthic mats, particularly near spring boils.

Sampling and chemical analyses-Measurements of discharge of the Ichetucknee River at U.S. Highway 27 and contributing springs during the period of each deployment were obtained from USGS gauges. We obtained ambient air temperature, solar radiation, and precipitation records from the Florida Automated Weather Network station (http://fawn.ifas.ufl.edu/) in Alachua, Florida, about $20 \mathrm{~km}$ from the study site. We sampled the six major spring inputs on dates during or close to sensor deployments (27 March, 24 April, 06 June, 10 October, 21 October) to determine $\mathrm{DO},\left[\mathrm{NO}_{3}^{-}\right]$, and temperature of spring inputs. We measured DO and temperature in the field using a Yellow Springs Instruments (YSI) 556 multiparameter probe. Water samples were collected in acid-washed prerinsed polyethylene bottles, stored on ice in the field, then frozen until analyzed for $\left[\mathrm{NO}_{3}^{-}\right]$based on second-derivative ultraviolet (UV) spectroscopy (Simal et al. 1985) using an Aquamate UV-Vis spectrophotometer.

We deployed in situ sensor arrays in the Ichetucknee River at U.S. 27 for four periods during the late spring (14 April-07 May and 14-18 May) and fall (01-04 October, 19 November-01 December) of 2008. The May and October deployments were shortened by instrument failure, which also prevented any nitrate measurements during an additional deployment (05-27 August 2008; temperature data from this deployment were used to evaluate hydrologic dispersion). Sensors were secured to maintain probes or intakes at a depth of $\sim 0.5 \mathrm{~m}$ in the advective zone of the river, and they recorded analytes at 1-h intervals. Dissolved oxygen and temperature were measured by a YSI 600XLM sonde equipped with a Clark cell for DO measurements. During the first three deployments, $\mathrm{NO}_{3}^{-}$was measured by a YSI 9600 in situ $\mathrm{NO}_{3}^{-}$sensor, which uses cadmiumreduction chemistry. During the November-December deployment, $\mathrm{NO}_{3}^{-}$was measured by an In Situ Ultraviolet Sensor (ISUS) version 3 (Satlantic; SN\#0123), which measures $\mathrm{NO}_{3}^{-}$using second-derivative UV spectroscopy. The ISUS was operated in the "triggered mode," with $70 \mathrm{~s}$ allotted for the UV lamp to warm up prior to measurement. $\mathrm{NO}_{3}^{-}$measurements were calculated by the ISUS (with the seawater bromide correction removed) as the mean of 10 
measurements collected over $20 \mathrm{~s}$. Burst statistics are unknown, but strong autocorrelation suggested low random noise, and subsequent tests revealed a sensor error rate at $20^{\circ} \mathrm{C}$ between 9 and $18 \mu \mathrm{g} \mathrm{L}^{-1}$.

Low turbidity $(<1$ nephelometric turbidity units [NTU]) in the Ichetucknee River permitted direct sampling of river water without pump filtration. Both the 9600 and the ISUS were equipped with copper guards and Nitex nylon mesh screening (nominal opening size: $100 \mu \mathrm{m}$ ) to reduce biofouling. We calibrated $\mathrm{NO}_{3}^{-}$sensors to standards and DO sensors to atmosphere prior to each deployment. Sensor deployments were limited to 3 weeks, a period over which we had determined that minimal biofouling and sensor drift occurred. For both $\mathrm{NO}_{3}^{-}$sensors, we validated sensors using field samples that were collected by an Isco autosampler and then analyzed in the laboratory using second derivative UV spectroscopy. Samples were collected every $4 \mathrm{~h}$ for $5 \mathrm{~d}$ during the May YSI deployment $(y=$ $0.98 x, r^{2}=0.94, p<0.001$, root mean square error $\left.[\mathrm{RSME}]=10.7 \mu \mathrm{g} \mathrm{N} \mathrm{L}^{-1}\right)$ and hourly for $24 \mathrm{~h}$ during the November ISUS deployment ( $y=1.02 x, r^{2}=0.91, p<$ 0.001 , RMSE $=13.0 \mu \mathrm{g} \mathrm{N} \mathrm{L}^{-1}$ ). In both cases, intercepts were not statistically different from zero.

Data analysis - We calculated gross primary production (GPP; $\mathrm{g} \mathrm{O}_{2} \mathrm{~m}^{-2} \mathrm{~d}^{-1}$ ) and ecosystem respiration (ER; $\mathrm{g} \mathrm{O}_{2}$ $\mathrm{m}^{-2} \mathrm{~d}^{-1}$ ) for each day of our deployments using the singlestation method (Owens 1974). Relationships between nighttime DO saturation deficit and DO change were strong for all days (mean $r^{2}=0.98$, range: $0.93-0.998$ ). Reaeration $(k)$, obtained from the slope of line relating the DO change per hour and the DO saturation deficit between 00:00 and 05:00 h, exhibited relatively little variation among days $\left(0.49 \pm 0.05 \mathrm{~h}^{-1}\right.$ [mean $\left.\left.\pm \mathrm{SD}\right]\right)$, but it was slightly, albeit significantly, higher in the spring $(0.51 \pm$ $\left.0.04 \mathrm{~h}^{-1}\right)$ than in the fall $\left(0.46 \pm 0.07 \mathrm{~h}^{-1}\right.$; Student's $t$-test: $t$ $=2.4 \mathrm{df}=18, p=0.024)$. Using estimates of flow velocity $\left(v ; \sim 25 \mathrm{~cm} \mathrm{~s}^{-1}\right)$, we estimated the areal extent integrated by metabolism measurements to be $\sim 5.4 \mathrm{~km} \mathrm{(} 3 v / k=3 \times$ $900 \mathrm{~m} \mathrm{~h}^{-1} / 0.5 \mathrm{~h}^{-1}$; Chapra and Di Toro 1991); this value is slightly greater than the length of the Ichetucknee River between the headspring and U.S. Highway 27.

From metabolism estimates, we calculated daily gross autotrophic assimilation $\left(U_{\mathrm{a}-\mathrm{GPP}} ; \mathrm{mg} \mathrm{N} \mathrm{m}^{-2} \mathrm{~d}^{-1}\right)$ assuming a photosynthetic coefficient of 1 , an autotrophic respiratory coefficient $\left(r_{\mathrm{a}}\right)$ of 0.5 (Hall and Tank 2003), and an autotrophic molar $\mathrm{C}: \mathrm{N}$ ratio of $25: 1$ (Canfield and Hoyer 1988). We calculated gross heterotrophic $\mathrm{N}$ assimilation $\left(U_{\text {het; }} \mathrm{mg} \mathrm{N} \mathrm{m}^{-2} \mathrm{~d}^{-1}\right)$ from heterotrophic respiration $\left(\mathrm{R}_{\mathrm{h}}=\right.$ ER $-r_{\mathrm{a}} \times$ GPP) assuming a heterotrophic growth efficiency of 0.20 and molar $\mathrm{C}: \mathrm{N}$ ratio of $20: 1$ (Hall and Tank 2003).

In combination with estimates of inputs from contributing springs, we used sensor measurements of $\left[\mathrm{NO}_{3}^{-}\right]$to construct hourly mass balance estimates of $\mathrm{N}$ removal, which we partitioned between autotrophic assimilation and other processes based on observed diel variation. We calculated assimilatory $\mathrm{N}$ demand from diel $\left[\mathrm{NO}_{3}^{-}\right]$ variation based on the integrated difference between an estimated $\mathrm{NO}_{3}^{-}$baseline (estimated using two different approaches) and observed diel variation (Fig. 1). Both approaches to baseline estimation first required a determination of the predawn peak of nitrate concentration $\left(\left[\mathrm{NO}_{3}^{-}\right]_{\max }\right)$. We calculated $\left[\mathrm{NO}_{3}^{-}\right]_{\max }$ for each date as the mean $\left[\mathrm{NO}_{3}^{-}\right]$during the predawn interval over which hourly means of $\left[\mathrm{NO}_{3}^{-}\right]$for each deployment were constant. We identified this interval as occurring between 03:00 and 04:00 $\mathrm{h}$ in the spring, and between 02:00 and 05:00 $\mathrm{h}$ in the fall, when nighttime $\left[\mathrm{NO}_{3}^{-}\right]$maxima were of longer duration (Heffernan et al. 2010).

Our first approach to calculate autotrophic $\mathrm{N}$ assimilation $\left(U_{\mathrm{a}-\mathrm{NO}_{3} \text {-pre }}\right.$; Fig. $\left.1 \mathrm{~A}\right)$ used the preceding $\left[\mathrm{NO}_{3}^{-}\right]_{\max }$ as the baseline for determining hourly $\mathrm{NO}_{3}^{-}$deficits attributed to autotrophic assimilation, and it was determined as:

$$
U_{\mathrm{a}-\mathrm{NO}_{3}-\mathrm{pre}}=\frac{Q}{A} \sum_{t=0}^{24}\left(\left[\mathrm{NO}_{3}^{-}\right]_{\max (0)}-\left[\mathrm{NO}_{3}^{-}\right]_{t}\right.
$$

where $U$ is uptake $\left(\mathrm{mg} \mathrm{N} \mathrm{m}^{-2} \mathrm{~d}^{-1}\right), Q$ is discharge $\left(\mathrm{L} \mathrm{h}^{-1}\right)$, $A$ is riverbed area $\left(\mathrm{m}^{2}\right), t$ is time of day $(\mathrm{h}),\left[\mathrm{NO}_{3}^{-}\right]_{\max (0)}$ is the preceding $\left[\mathrm{NO}_{3}^{-}\right]_{\max }$, and $\left[\mathrm{NO}_{3}^{-}\right]_{t}$ is nitrate concentration (mg N L $\left.{ }^{-1}\right)$ at time $t$. Our second approach $\left(U_{\mathrm{a}_{-} \mathrm{NO}_{3} \text {-int; }}\right.$; Fig. 1B) used a baseline interpolated between the preceding and subsequent $\left[\mathrm{NO}_{3}^{-}\right]_{\max }$ and was determined as:

$$
\begin{aligned}
U_{\mathrm{a}-\mathrm{NO}_{3}-\mathrm{int}}= & \frac{Q}{A} \sum_{t=0}^{24}\left(\left[\mathrm{NO}_{3}^{-}\right]_{\max (0)} \times\left(1-\frac{t}{24 \mathrm{~h}}\right)\right. \\
& +\left[\mathrm{NO}_{3}^{-}\right]_{\max (24)} \times\left(\frac{t}{24 \mathrm{~h}}\right)-\left[\mathrm{NO}_{3}^{-}\right]_{t}
\end{aligned}
$$

where $\left[\mathrm{NO}_{3}^{-}\right]_{\max (24)}$ is the subsequent $\left[\mathrm{NO}_{3}^{-}\right]_{\max }$. Equations 1 and 2 differ primarily in their response to baseline movement. When the subsequent $\left[\mathrm{NO}_{3}^{-}\right]_{\max }$ is greater than the preceding $\left[\mathrm{NO}_{3}^{-}\right]_{\max }, U_{\mathrm{a}-\mathrm{NO}_{3} \text {-pre }}$ will be lower than would be the case if the two baseline estimates were equal (Fig. 1A); in contrast, $U_{\mathrm{a}-\mathrm{NO}_{3} \text {-int }}$ increases with day-to-day increases in $\left[\mathrm{NO}_{3}^{-}\right]_{\max }$ (Fig. 1B). Equations 1 and 2 share the assumption that variation in $\mathrm{NO}_{3}^{-}$accounts for all variation in dissolved inorganic nitrogen (DIN). Low concentrations of ammonium in the Ichetucknee River (Heffernan et al. 2010) suggest that $\mathrm{N}$ mineralized from sediment OM pools is either assimilated by biota or nitrified in the oxic surface waters of the Ichetucknee; as a consequence, the diel $\mathrm{NO}_{3}^{-}$approach will account for assimilation of $\mathrm{NH}_{4}^{+}$as well as direct uptake of $\mathrm{NO}_{3}^{-}$.

Using our estimates of $U_{\text {het }}$ from metabolism measurements, together with $\mathrm{NO}_{3}^{-}$inputs, we can calculate areal denitrification rate $\left(U_{\mathrm{den}} ; \mathrm{mg} \mathrm{N} \mathrm{m} \mathrm{N}^{-2} \mathrm{~d}^{-1}\right)$ by difference (Fig. 1B):

$$
U_{\text {den }}=\frac{Q}{A}\left(\left[\mathrm{NO}_{3}^{-}\right]_{\text {springs }}-\left[\mathrm{NO}_{3}^{-}\right]_{\max }\right)-U_{\text {het }}
$$

where $\left[\mathrm{NO}_{3}^{-}\right]_{\text {springs }}$ is the flow-weighted mean $\left[\mathrm{NO}_{3}^{-}\right]$of spring discharge. In calculating $U_{\text {den }}$ from Eq. 3 , we have assumed that $\left[\mathrm{NO}_{3}^{-}\right]_{\text {springs }}$ is constant over the course of each deployment; this assumption is supported by the high monthly serial autocorrelation $(r=+0.88)$ over nearly two decades of monthly $\left[\mathrm{NO}_{3}^{-}\right]$measurements in the Ichetucknee River, and similar temporal stability of contributing 


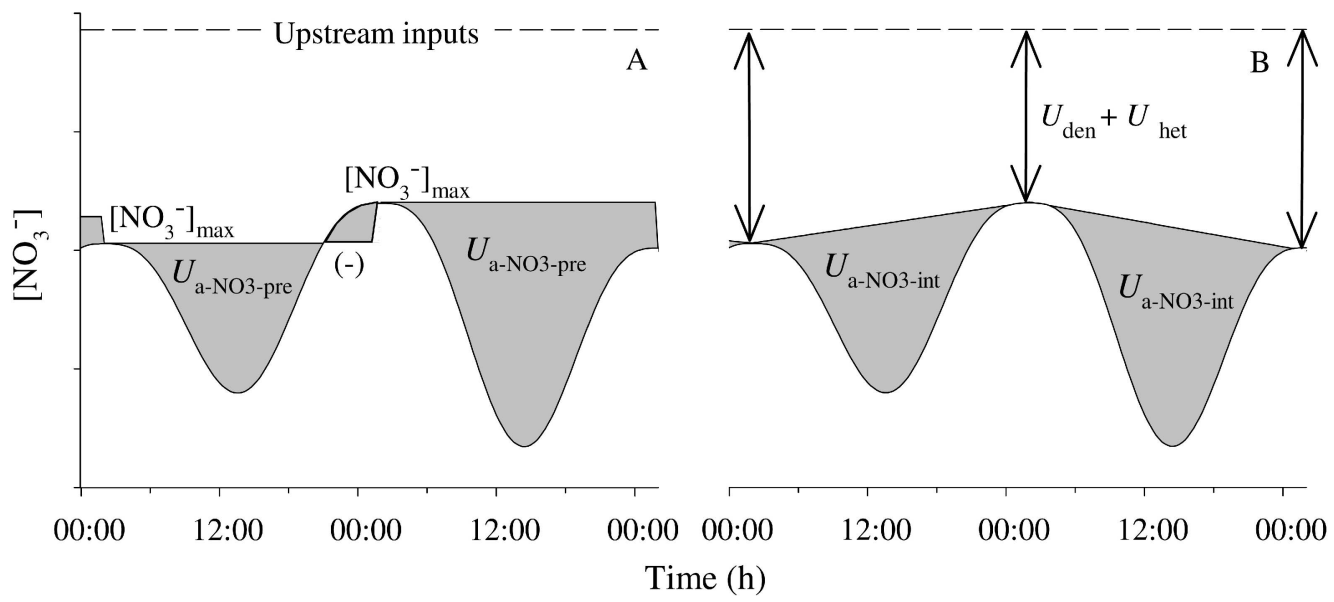

Fig. 1. Estimation of autotrophic assimilation and denitrification from diel $\mathrm{NO}_{3}^{-}$variation and upstream inputs, based on two approaches to setting $\mathrm{NO}_{3}^{-}$baseline. (A) Estimation of autotrophic assimilation $\left(U_{\mathrm{a}-\mathrm{NO}_{3} \text {-pre }}\right)$ via extrapolation of preceding predawn nitrate concentrations $\left(\left[\mathrm{NO}_{3}^{-}\right]_{\max }\right)$. (B) Estimation of autotrophic assimilation $\left(U_{\mathrm{a}-\mathrm{NO}_{3} \text {-int }}\right)$ via interpolation between adjacent $\left[\mathrm{NO}{ }_{3}^{-}\right]_{\text {max }}$. Arrows in (B) illustrate that the sum of denitrification $\left(U_{\text {den }}\right)$ and heterotrophic assimilation $\left(U_{\text {het }}\right)$ is calculated from the difference between inputs and $\left[\mathrm{NO}_{3}^{-}\right]_{\max }$, but $U_{\text {den }}$ and $U_{\text {het }}$ were calculated in the same manner irrespective of the approach used to estimate

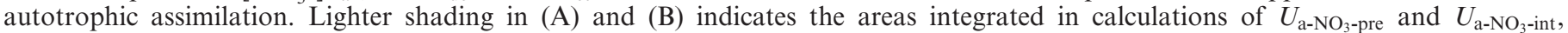
respectively. Darker shading in (A) indicates areas where variation in $\left[\mathrm{NO}_{3}^{-}\right]_{\max }$ yields observations systematically greater than the $\mathrm{NO}_{3}^{-}$ baseline. Resulting negative values were incorporated into calculations of $U_{\mathrm{a}-\mathrm{NO}_{3} \text {-pre }}$.

springs (coefficient of variation $<7 \%$ for all springs from 10 consecutive monthly samples; Heffernan et al. 2010).

Equations 1-3 all assume that $\left[\mathrm{NO}_{3}^{-}\right]_{\max }$ represents the absence of autotrophic assimilation, an assumption that could be violated either by active physiological assimilation at the time of $\left[\mathrm{NO}_{3}^{-}\right]_{\max }$, or by hydrologic dispersion that produces substantial contributions at the time of $\left[\mathrm{NO}_{3}^{-}\right]_{\max }$ from parcels of water with long residence times and thus depleted $\left[\mathrm{NO}_{3}^{-}\right]$. Given that this assumption holds, it follows that variation in $\left[\mathrm{NO}_{3}^{-}\right]_{\max }$ reflects variation in some combination of upstream inputs and assimilatory or dissimilatory heterotrophic $\mathrm{N}$ removal (Eq. 3). An additional assumption of Eq. 1-3 is that inputs of inorganic $\mathrm{N}$ from sediment nutrient remineralization and spring discharge are constant over the course of the day. While we cannot evaluate this assumption with respect to sediment remineralization, deployment of sensors in two springs (Cedar Hole and Mill Pond) for periods of several months showed no evidence of any diel variation ( $T$. R. Rayfield unpubl.). Estimates of all processes were calculated using Ichetucknee River discharge, rather than that of contributing springs. Because the Ichetucknee River is typically losing, estimates based on river discharge may be $\sim 10 \%$ lower than those based on springs discharge (Heffernan et al. 2010).

We used diel patterns of air and river temperature to evaluate the magnitude of hydrologic dispersion that might confound estimates of assimilation from diel $\mathrm{NO}_{3}^{-}$ variation. Our approach took advantage of the fact that during late fall and summer deployments, air temperature $\left(T_{A}\right)$ maxima (fall) or minima (summer) were very close to the flow-weighted temperature of springs inputs $\left(\mathrm{T}_{\mathrm{S}}=\right.$ $21.7^{\circ} \mathrm{C}$ ), meaning that air temperatures were virtually always less than (in the fall) or greater than (in the summer) the temperature of springs inflows (Fig. 2; summer data not shown). Thus, if hydrologic dispersion creates longer-residence flow paths of sufficient magnitude to influence $\left[\mathrm{NO}_{3}^{-}\right]_{\max }$, then we would expect river temperatures $\left(\mathrm{T}_{\mathrm{W}}\right)$ to reflect that influence as well. After normalizing air and river temperatures to $\mathrm{T}_{\mathrm{S}}$ (i.e., $\Delta \mathrm{T}_{\mathrm{A}}=$ $\mathrm{T}_{\mathrm{A}}-\mathrm{T}_{\mathrm{S}}$ ), we used linear regression to predict daily minimum river temperature $\left(\Delta \mathrm{T}_{\mathrm{W}-\mathrm{min}}\right)$ from daily minimum air temperature $\left(\Delta \mathrm{T}_{\mathrm{A} \text {-min }}\right)$ during the summer deployment and daily maximum river temperature $\left(\Delta \mathrm{T}_{\mathrm{W} \text {-max }}\right)$ from daily maximum air temperature $\left(\Delta \mathrm{T}_{\mathrm{A}-\max }\right)$ during the fall. If our assumption of negligible influence of hydrologic dispersion is correct, we would expect those relationships to pass through the origin. Large dispersion would cause intercepts to be negative in the fall and positive in the summer, reflecting ambient air-river temperature gradients. We did not use April, May, or October temperature records in this analysis because temperature gradients between the river and atmosphere switched sign over the course of most days. We assumed that river hydraulics were relatively constant in light of minimal flow variability.

We used multiple regression analysis to evaluate daily insolation and temperature as predictors of GPP. We used bivariate regression to evaluate the relationship between $\mathrm{N}$ assimilation estimates derived from GPP and from diel $\mathrm{NO}_{3}^{-}$variation $\left(U_{\mathrm{a}-\mathrm{NO}_{3} \text {-pre }}\right.$ and $\left.U_{\mathrm{a}-\mathrm{NO}_{3} \text {-int }}\right)$, across all dates and within the spring and fall seasons. We also evaluated seasonal differences in GPP and $U_{\mathrm{a}-\mathrm{NO}_{3}}$ using Student's $t$ test. Linear regression was also used to determine relationships between GPP and $U_{\text {den }}$ across all dates. We compared the fit of linear and quadratic equations to the relationship between hourly GPP (based on DO) and hourly $\mathrm{NO}_{3}^{-}$assimilation (as estimated from $U_{\mathrm{a}-\mathrm{NO}_{3} \text {-pre }}$ ) separately for spring and fall data. To test the hypothesis that day-to-day changes in $\left[\mathrm{NO}_{3}^{-}\right]_{\max }$ were driven by the coupling of photosynthesis and denitrification, we calcu- 

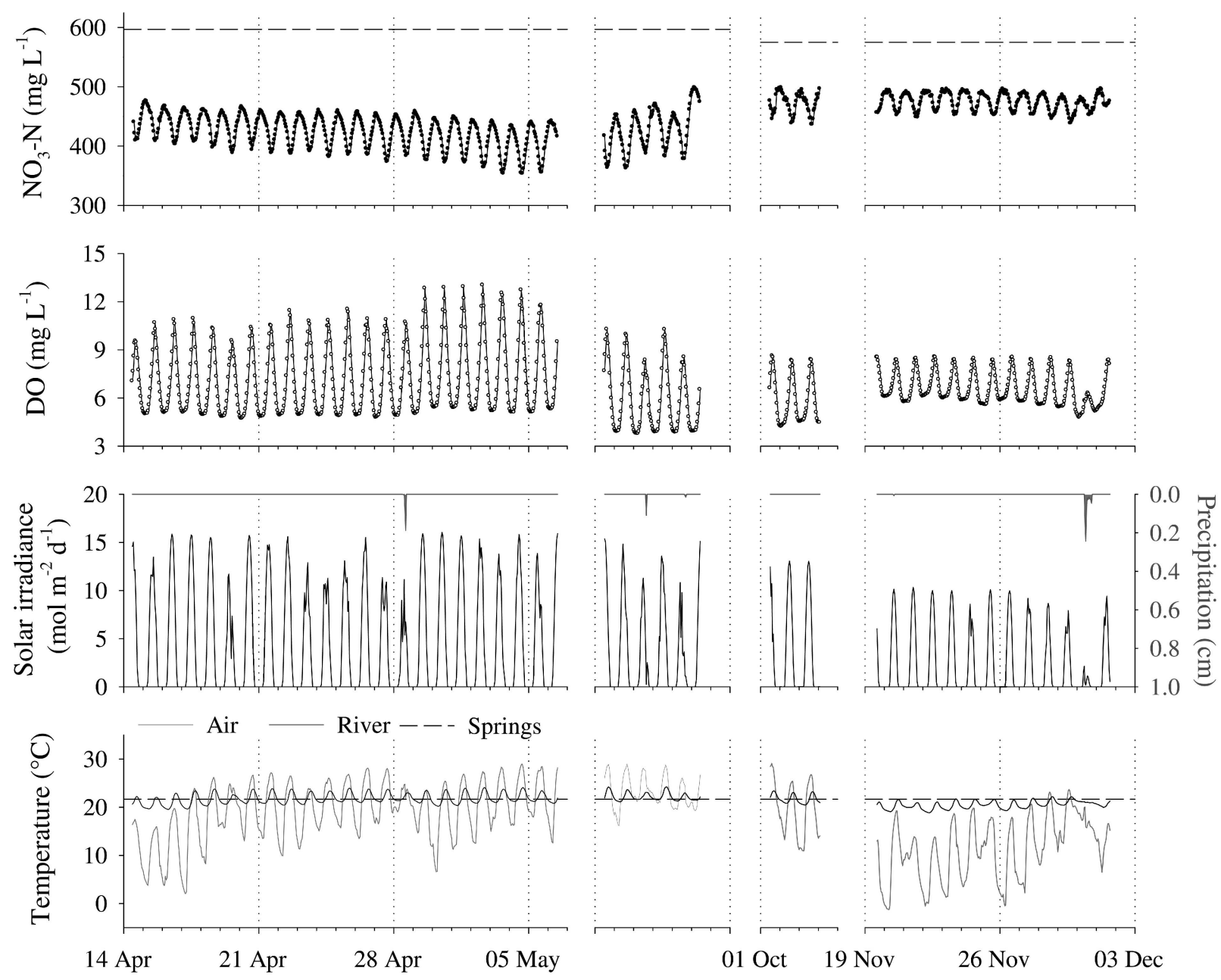

14 May 21 May

2008

Fig. 2. Temporal patterns of $\mathrm{NO}_{3}^{-}$, DO, insolation, and precipitation, and river and air temperatures in the Ichetucknee River during four periods between April and November 2008. Dashed lines in the upper panel indicate flow-weighted $\mathrm{NO}_{3}^{-}$concentration of springs inputs.

lated $\Delta$ insolation, $\Delta \mathrm{GPP}, \Delta \mathrm{ER}, \Delta\left[\mathrm{NO}_{3}^{-}\right]_{\max }$, and $\Delta U_{\mathrm{den}}$ as the day-to-day difference in each variable (i.e., day ${ }_{i+1}-$ day $\left._{i}\right)$. We used linear regression to evaluate $\Delta$ insolation as a predictor of $\Delta \mathrm{GPP}$, and to evaluate $\Delta \mathrm{GPP}$ as a predictor of $\Delta \mathrm{ER}, \Delta\left[\mathrm{NO}_{3}^{-}\right]_{\max }$ and $\Delta U_{\mathrm{den}}$. We evaluated the relationship between precipitation and $\Delta\left[\mathrm{NO}_{3}^{-}\right]_{\max }$ to test the alternative hypothesis that variation in $\left[\mathrm{NO}_{3}^{-}\right]_{\max }$ reflected precipitation-driven variation in springs inputs, rather than variation in $U_{\text {den }}$ and/or $U_{\text {het }}$. Regressions were checked for assumptions of constant variance and linearity, but we observed no deviations sufficient to warrant transformations. We used SPSS statistical software (version 17.0) for all statistical analyses.

\section{Results}

Dissolved oxygen, $\left[\mathrm{NO}_{3}^{-}\right]$, and temperature exhibited marked and regular diel variation (Fig. 2). Mean DO minima (03:00 and 02:00 $\mathrm{h}$ on average during spring and fall, respectively) and maxima (15:00 $\mathrm{h}$ during both spring and fall) were 4.8 and $10.9 \mathrm{mg} \mathrm{L}^{-1}$, respectively, during the spring and 4.8 and $7.8 \mathrm{mg} \mathrm{L}^{-1}$, respectively, during the fall. On average, $\left[\mathrm{NO}_{3}^{-}\right]$ranged from 381 to $456 \mu \mathrm{g} \mathrm{NO}_{3}-\mathrm{N} \mathrm{L}^{-1}$ during the spring (with minima and maxima at $16: 00 \mathrm{~h}$ and 03:00 $\mathrm{h}$, respectively) and from 451 to $488 \mu \mathrm{g} \mathrm{NO}_{3}-\mathrm{N} \mathrm{L}^{-1}$ during the fall deployment (with minima and maxima at16:00 $\mathrm{h}$ and 02:00 $\mathrm{h}$, respectively). River $\left[\mathrm{NO}_{3}^{-}\right]$was uniformly below the flow-weighted average spring concentrations $\left(\left[\mathrm{NO}_{3}^{-}\right]_{\text {springs }}\right)$ in both spring $\left(597 \mu \mathrm{g} \mathrm{NO}_{3}-\mathrm{N} \mathrm{L}^{-1}\right)$ and fall $\left(575 \mu \mathrm{g} \mathrm{NO}{ }_{3}-\mathrm{N} \mathrm{L}^{-1}\right.$ ). Mean minimum and maximum river temperatures were $20.8^{\circ} \mathrm{C}(07: 00 \mathrm{~h})$ and $23.5^{\circ} \mathrm{C}(17: 00 \mathrm{~h})$ during the spring, $21.8^{\circ} \mathrm{C}(07: 00 \mathrm{~h})$ and $23.6^{\circ} \mathrm{C}(18: 00 \mathrm{~h})$ in the summer, and $19.9^{\circ} \mathrm{C}(08: 00 \mathrm{~h})$ and $21.8^{\circ} \mathrm{C}(17: 00 \mathrm{~h})$ during the fall. Summer $\Delta \mathrm{T}_{\mathrm{W} \text {-min }}$ and fall $\Delta \mathrm{T}_{\mathrm{W}-\max }$ were significantly correlated with $\Delta \mathrm{T}_{\mathrm{A}-\min }$ (slope: 0.054 [95\% CI: $0.036-0.073$ ], intercept: -0.026 [95\% CI: $-0.077-0.024], r^{2}=0.65, p<0.0001$ ) and $\Delta \mathrm{T}_{\mathrm{A}-\max }$ (slope: 0.100 [95\% CI: $0.083-0.118$ ], intercept: -0.025 [95\% CI: $-0.105-0.055$ ], $\left.r^{2}=0.89, p<0.0001\right)$, respectively, and intercepts were not statistically different from zero (Fig. 3). 


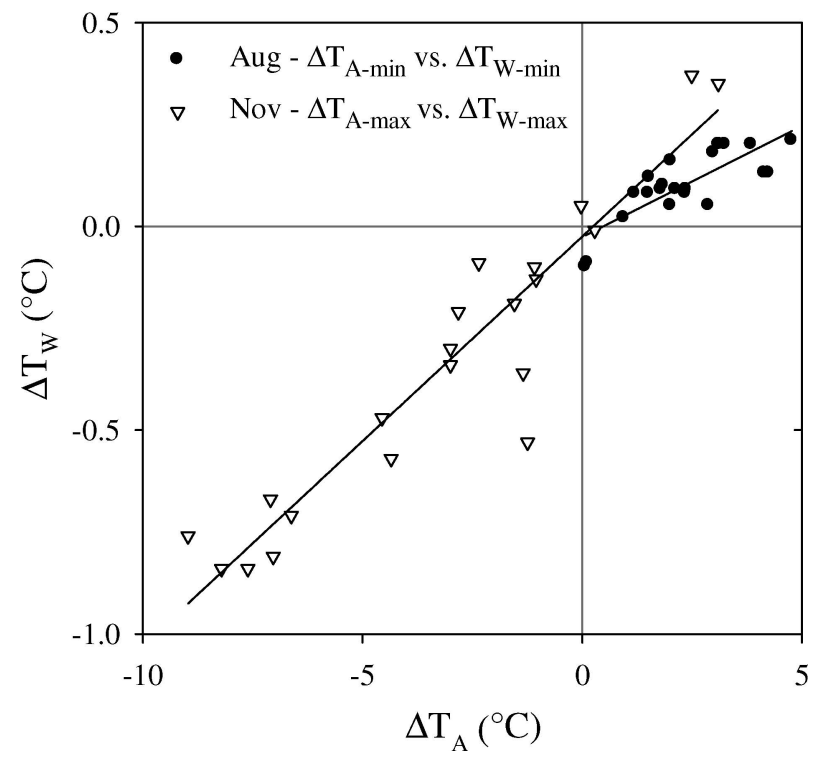

Fig. 3. Air temperature $\left(\Delta \mathrm{T}_{\mathrm{A}} ; x\right.$-axis $)$ effects on river-water temperature $\left(\Delta \mathrm{T}_{\mathrm{W}} ; y\right.$-axis), both presented relative to spring-water input temperature $\left(\mathrm{T}_{\mathrm{S}}=21.65^{\circ} \mathrm{C} ; \Delta \mathrm{T}_{\mathrm{A}}=\mathrm{T}_{\mathrm{A}}-\mathrm{T}_{\mathrm{S}}\right)$. Strong correlations are observed between maximum $\Delta \mathrm{T}_{\mathrm{A}}$ and subsequent $\left(\sim 4 \mathrm{~h}\right.$ later) maximum $\Delta \mathrm{T}_{\mathrm{W}}$ in fall $\left(\mathrm{T}_{\mathrm{A}}<\mathrm{T}_{\mathrm{S}}\right)$, and between minimum $\Delta \mathrm{T}_{\mathrm{A}}$ and subsequent minimum $\Delta \mathrm{T}_{\mathrm{W}}$ in summer $\left(\mathrm{T}_{\mathrm{A}}>\right.$ $\mathrm{T}_{\mathrm{S}}$ ). Note that both fitted lines pass through the origin, suggesting minimal contributions from longer-residence flow paths exposed to cooler or warmer temperatures, and therefore negligible hydrologic dispersion.

We observed substantial differences in metabolism between spring and fall deployments. During the spring deployments, GPP averaged $14.3 \pm 0.4 \mathrm{~g} \mathrm{O}_{2} \mathrm{~m}^{-2} \mathrm{~d}^{-1}$ (mean $\pm \mathrm{SE}$ ) and ranged from 9.2 to $16.8 \mathrm{~g} \mathrm{O}_{2} \mathrm{~m}^{-2} \mathrm{~d}^{-1}$. In the fall, GPP averaged $5.8 \pm 0.4 \mathrm{~g} \mathrm{O}_{2} \mathrm{~m}^{-2} \mathrm{~d}^{-1}$, and ranged from 2.6 to $8.9 \mathrm{~g} \mathrm{O}_{2} \mathrm{~m}^{-2} \mathrm{~d}^{-1}$. Across all dates, insolation and river temperature explained $\sim 87 \%$ of the variation in GPP $(\mathrm{df}=34, p<0.0001)$. Spring ER averaged $8.7 \pm 0.2 \mathrm{~g}$ $\mathrm{O}_{2} \mathrm{~m}^{-2} \mathrm{~d}^{-1}$, and ranged from 7.3 to $10.3 \mathrm{~g} \mathrm{O}_{2} \mathrm{~m}^{-2} \mathrm{~d}^{-1}$. Fall ER averaged $8.2 \pm 0.4 \mathrm{~g} \mathrm{O}_{2} \mathrm{~m}^{-2} \mathrm{~d}^{-1}$, and ranged from 6.2 to $10.9 \mathrm{~g} \mathrm{O}_{2} \mathrm{~m}^{-2} \mathrm{~d}^{-1}$. Based on these measurements, we estimated $U_{\text {a-GPP }}$ as $125 \pm 3 \mathrm{mg} \mathrm{N} \mathrm{m}^{-2} \mathrm{~d}^{-1}$ and $51 \pm 4 \mathrm{mg}$ $\mathrm{N} \mathrm{m}^{-2} \mathrm{~d}^{-1}$ during the spring and fall, respectively. We estimated $U_{\text {het }}$ to be $7 \pm 1 \mathrm{mg} \mathrm{N} \mathrm{m}^{-2} \mathrm{~d}^{-1}$ and $23 \pm 1 \mathrm{mg} \mathrm{N}$ $\mathrm{m}^{-2} \mathrm{~d}^{-1}$ during the same periods.

Productivity and $\mathrm{NO}_{3}^{-}$dynamics corresponded closely at hourly, daily, and seasonal timescales. Seasonal means of assimilation estimates based on diel $\mathrm{NO}_{3}^{-}$variation were similar to those obtained from GPP measurements. Spring means of $U_{\mathrm{a}-\mathrm{NO}_{3} \text {-pre }}$ and $U_{\mathrm{a}-\mathrm{NO}_{3} \text {-int }}$ were $131.0 \pm 3.7$ and $131.7 \pm 2.4 \mathrm{mg} \mathrm{N} \mathrm{m} \mathrm{N}^{-2} \mathrm{~d}^{-1}$, respectively. In the fall, $U_{\mathrm{a}-\mathrm{NO}_{3} \text {-pre }}$ and $U_{\mathrm{a}-\mathrm{NO}_{3} \text {-int }}$ were $58.3 \pm 4.9$ and $58.5 \pm 4.2 \mathrm{mg}$ $\mathrm{N} \mathrm{m}^{-2} \mathrm{~d}^{-1}$. Across all days, autotrophic assimilation estimates from diel $\mathrm{NO}_{3}^{-}$variation were strongly correlated with $U_{\mathrm{a}-\mathrm{GPP}}$, but the relationship was stronger for $U_{\mathrm{a}-\mathrm{NO}_{3} \text {-pre }}$ $\left(r^{2}=0.93, p<0.0001 ;\right.$ Fig. 4A) than for $U_{\mathrm{a}-\mathrm{NO}_{3} \text {-int }}\left(r^{2}=\right.$ $0.81, p<0.0001$; Fig. 4B). The relationship between $U_{\mathrm{a}-\mathrm{GPP}}$ and $U_{\mathrm{a}-\mathrm{NO}_{3} \text {-pre }}$ had a slope (0.97) that could not be distinguished from unity and an intercept not statistically different from zero (9.8; Table 1); in contrast, the slope between $U_{\mathrm{a}-\mathrm{GPP}}$ and $U_{\mathrm{a}-\mathrm{NO}_{3} \text {-int }}(0.86)$ was significantly less than one and the intercept was significantly greater than zero (20.9). These patterns were largely driven by seasonal variation in both productivity and diel $\mathrm{NO}_{3}^{-}$amplitude, but $U_{\mathrm{a}-\mathrm{GPP}}$ and $U_{\mathrm{a}-\mathrm{NO}_{3} \text {-pre }}$ were also strongly correlated within individual seasons (spring: $y=0.84 x+26.3, r^{2}=$ $0.55, p<0.0001$; fall: $y=1.19 x-1.5, r^{2}=0.92, p$ $<0.0001)$. $U_{\mathrm{a}-\mathrm{GPP}}$ and $U_{\mathrm{a}-\mathrm{NO}_{3} \text {-int }}$ were significantly correlated in the fall $\left(y=0.83 x+16.6, r^{2}=0.60, p<0.005\right)$ but not in the spring season $\left(r^{2}<0.001, p=0.90\right)$.

The relationship between GPP and $\mathrm{N}$ assimilation $\left(U_{\mathrm{a}-\mathrm{NO}_{3} \text {-pre }}\right)$ at hourly intervals exhibited slight but significant nonlinearity in the spring $\left(y=0.72+10.6 x-2.2 x^{2}, r^{2}\right.$ $=0.90, p<0.0001$ ), with decreasing $\mathrm{NO}_{3}^{-}$assimilation per unit production (Fig. 5A), but the relationship was linear during the fall $\left(y=0.52+7.8 x, r^{2}=0.77, p<0.0001\right.$; Fig. 5B). During both seasons, the relationship between GPP and $\mathrm{N}$ assimilation was hysteretic, with greater $\mathrm{N}$ assimilation per unit productivity during periods of decreasing DO. In the spring, we also observed small predawn increases in apparent $\mathrm{NO}_{3}^{-}$assimilation that preceded early morning increases in $\mathrm{O}_{2}$ production (Fig. 5A).

Loss of $\mathrm{N}$ via denitrification was greater than combined autotrophic and heterotrophic demand, and it varied both seasonally and in response to interday variation in GPP. $U_{\text {den }}$ was higher in the spring $(568 \pm 10 \mathrm{mg} \mathrm{NO}-\mathrm{N}$ $\left.\mathrm{m}^{-2} \mathrm{~d}^{-1}\right)$ than in the fall $\left(288 \pm 16 \mathrm{mg} \mathrm{NO}_{3}-\mathrm{N} \mathrm{m}^{-2} \mathrm{~d}^{-1} ; t\right.$ $=24.9$, df $=34, p<0.0001$ ), and $U_{\text {den }}$ was positively correlated with GPP across all dates $\left(y=30.4 x+146.7, r^{2}\right.$ $=0.89$, $\mathrm{df}=37, p<0.0001)$. Day-to-day changes in insolation explained more than $50 \%$ of the variation in $\Delta$ GPP (Fig. 6A). Day-to-day changes in $\left[\mathrm{NO}_{3}^{-}\right]_{\max }$ were weakly but significantly correlated with precipitation $(y=$ $4.7 x-0.4, r^{2}=0.12, p<0.05$; Fig. 6B), but the correlation between $\Delta$ GPP and $\Delta\left[\mathrm{NO}_{3}^{-}\right]_{\max }$ was much stronger $\left(y=-4.9 \mathrm{x}-0.13, r^{2}=0.72, p<0.0001\right.$; Fig. 6C). The latter relationship was significant even when the 2 days following each rain event were excluded from the analysis $\left(r^{2}=0.35, \mathrm{df}=25, p<0.001\right)$. Day-to-day changes in ER were uncorrelated with $\Delta \mathrm{GPP}\left(r^{2}=0.07\right.$, df $=34, p=0.13)$. Since ER and thus $U_{\text {het }}$ exhibited relatively little variability, $\triangle \mathrm{GPP}$ was also strongly correlated with $\Delta U_{\text {den }}$ (Fig. 6D).

\section{Discussion}

The results of this study demonstrate that $\mathrm{NO}_{3}^{-}$ dynamics in the Ichetucknee River are linked to primary productivity at a variety of temporal scales via both direct and indirect mechanisms. The strong relationship between daily GPP and $\mathrm{N}$ assimilation in the Ichetucknee River suggests that the well-established link between metabolism and $\mathrm{N}$ uptake in smaller streams (Roberts and Mulholland 2007; Valett et al. 2008) also holds for larger systems. In addition, we have demonstrated that high-resolution in situ measurements can be used to discriminate among $\mathrm{N}$ removal mechanisms and evaluate dynamics of those processes at temporal scales (i.e., day-to-day variation) that are intractable to address with other methods. 


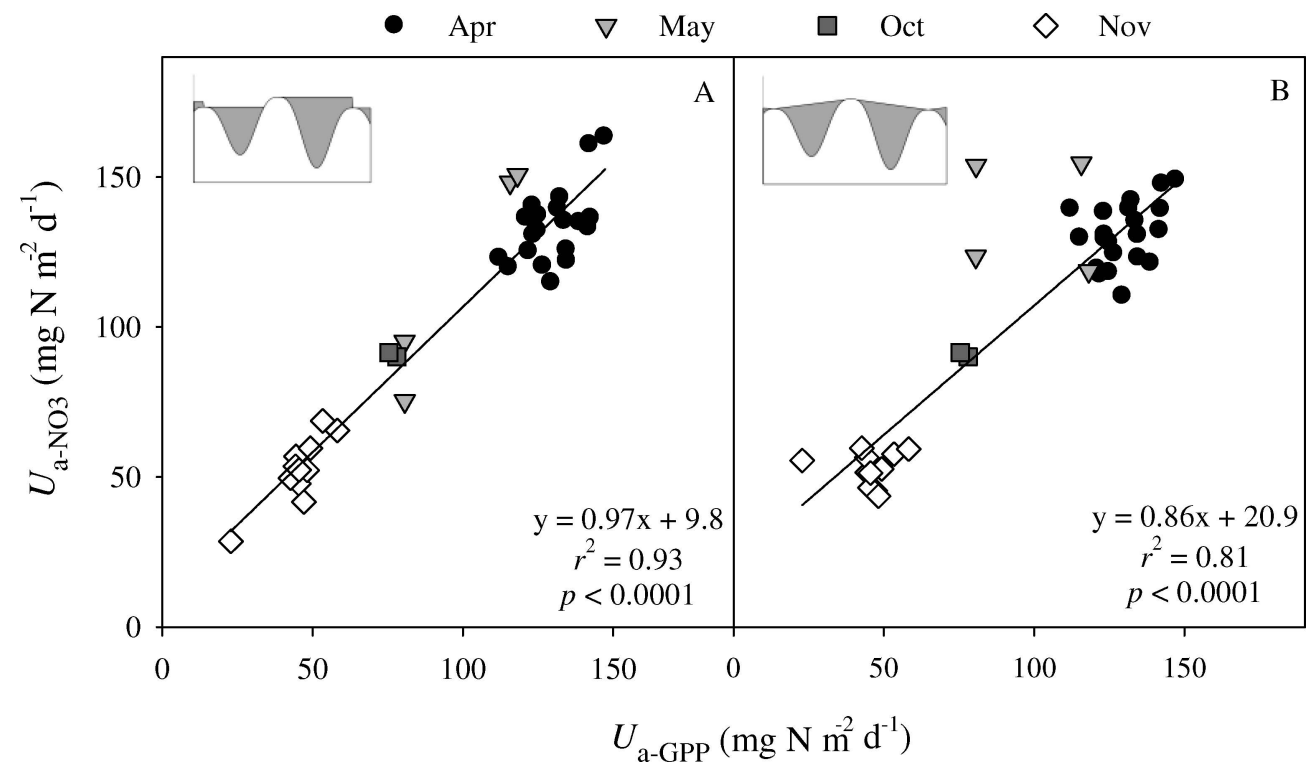

Fig. 4. Relationships between daily $\mathrm{N}$ assimilation in the Ichetucknee River predicted from gross primary production $\left(U_{\mathrm{a}-\mathrm{GPP}}\right)$ and estimated from diel $\mathrm{NO}_{3}$ curves via $(\mathrm{A})$ extrapolation of preceding $\left[\mathrm{NO}_{3}^{-}\right]_{\max }\left(U_{\mathrm{a}-\mathrm{NO}_{3} \text {-pre }}\right)$ and $(\mathrm{B})$ interpolation between $\left[\mathrm{NO}_{3}^{-}\right]_{\max }\left(U_{\mathrm{a}-\mathrm{NO}_{3} \text {-int }}\right)$. Lines are best-fit based on least-square-mean regression.

Diel patterns: Direct coupling of photosynthesis and $\mathrm{NO}_{3}^{-}$dynamics - At fine temporal resolution, patterns of DO and $\mathrm{NO}_{3}^{-}$exhibited several subtle but interesting nonlinearities. Diurnal hysteresis between GPP and $\mathrm{NO}_{3}^{-}$ assimilation, like that observed in the Ichetucknee River (Fig. 5), has also been observed in high-productivity streams by Mulholland et al. (2006), who hypothesized that these lags may reflect the high energetic costs of $\mathrm{NO}_{3}^{-}$ assimilation. The slight nonlinearity in the relationship between GPP and $U_{\mathrm{a}-\mathrm{NO}_{3} \text {-pre }}$ during the spring may indicate changes in autotroph stoichiometry in response to diel changes in light-nutrient ratios, but it could also reflect greater photorespiration under midday high-light conditions. Small predawn declines in $\left[\mathrm{NO}_{3}^{-}\right]$prior to increases in DO may reflect either anticipatory uptake by vegetation or minor diel variation in other mechanisms of $\mathrm{NO}_{3}^{-}$ removal.

Despite the minor nonlinearities observed at hourly resolution, we observed an extremely strong correlation between the magnitude of diel $\mathrm{NO}_{3}^{-}$variation and daily
GPP. This pattern was partly driven by seasonal variation in GPP and the magnitude of diel $\mathrm{NO}_{3}^{-}$variation, but correlations within seasons were also strong for the relationship between $U_{\mathrm{a}-\mathrm{GPP}}$ and $U_{\mathrm{a}-\mathrm{NO}_{3} \text {-pre }}$. At the seasonal scale, $U_{\mathrm{a}-\mathrm{NO}_{3} \text {-pre }}$ overestimated $U_{\mathrm{a}-\mathrm{GPP}}$ by $<5 \%$ during the spring, but by $\sim 15 \%$ in the fall when productivity was lower. This observation, like the nonlinearity observed in hourly measurements during the spring, is consistent with the negative relationship between light intensity and autotroph nutrient content observed in both unicellular and vascular plants (reviewed by Sterner and Elser 2002).

The first basic assumption of our diel $\mathrm{NO}_{3}^{-}$approach is that $\left[\mathrm{NO}_{3}^{-}\right]_{\max }$ represents the absence of any autotrophic assimilation. This assumption could be violated if either plants were actively assimilating at that time, or if hydrologic dispersion were of sufficient magnitude that predawn $\left[\mathrm{NO}_{3}^{-}\right.$] was influenced by parcels of water where $\left[\mathrm{NO}_{3}^{-}\right]$reflected assimilation during the previous day. Relationships between river and air temperature minima and maxima exhibited no bias away from the origin,

Table 1. Results of linear regression analyses of relationships between estimates of daily autotrophic $\mathrm{N}$ assimilation derived from measurement of gross primary production $\left(U_{\mathrm{a}-\mathrm{GPP}}\right)$ and estimated from diel $\mathrm{NO}_{3}^{-}$curves via extrapolation of preceding $\left[\mathrm{NO}_{3}^{-}\right]_{\text {max }}$ $\left(U_{\mathrm{a}-\mathrm{NO}_{3} \text {-pre }}\right)$ and interpolation between nightly $\left[\mathrm{NO}_{3}^{-}\right]_{\max }\left(U_{\mathrm{a}-\mathrm{NO}_{3} \text {-int }}\right)$ for all dates. $\mathrm{SS}$, sum of squares, MSE, mean square error.

\begin{tabular}{lrrrcccc}
\hline \hline \multicolumn{1}{c}{ Effect } & \multicolumn{1}{c}{$\mathrm{SS}$} & $\mathrm{df}$ & $\mathrm{MSE}$ & $F$ & $p$ & $\beta_{0}(95 \% \mathrm{CI})$ & $\beta_{1}(95 \% \mathrm{CI})$ \\
\hline$U_{\mathrm{a}-\mathrm{NO}_{3} \text {-pre }}$ & & & & & & & \\
$\quad$ Regression $\left(U_{\mathrm{a}-\mathrm{GPP}}\right)$ & 52,842 & 1 & 52,842 & 447.7 & $<0.0001$ & $9.8(-0.1-19.7)$ & $0.97(0.88-1.06)$ \\
$\quad$ Error & 4249 & 36 & 118.0 & & & & \\
$U_{\mathrm{a}-\mathrm{NO}_{3} \text {-int }}$ & & & & & & & \\
$\quad$ Regression $\left(U_{\mathrm{a}-\mathrm{GPP}}\right)$ & 44,184 & 1 & 44,184 & 149.0 & $<0.0001$ & $20.9(5.6-36.2)$ & $0.86(0.72-1.00)$ \\
$\quad$ Error & 10,107 & 36 & 280.7 & & & & \\
\hline
\end{tabular}




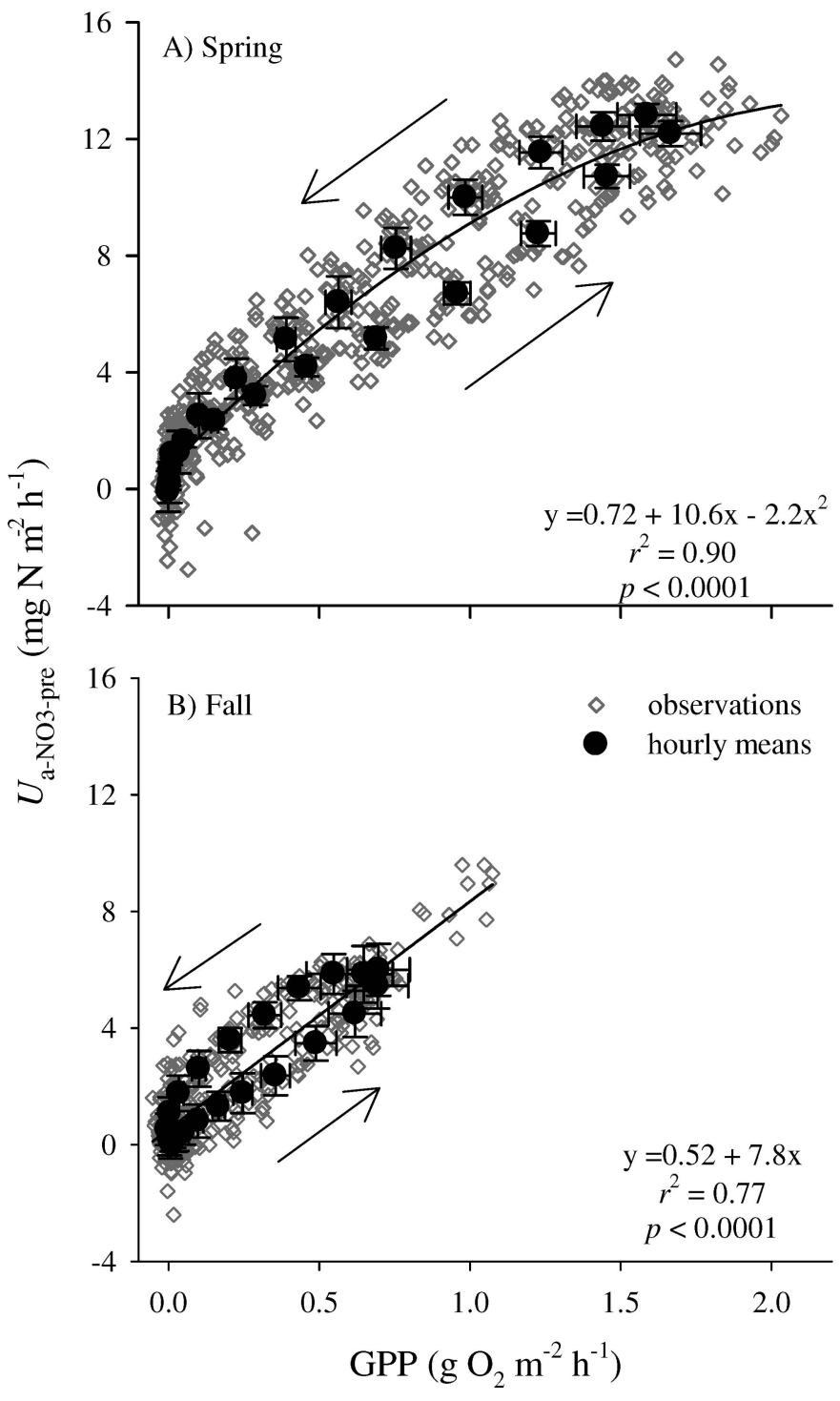

Fig. 5. Relationships between hourly GPP and N flux deficit in the Ichetucknee River during (A) spring and (B) fall, indicating lags between photosynthesis and $\mathrm{N}$ assimilation. Arrows indicate direction of change during periods of increasing and decreasing DO. Lines are best-fit least-mean-square regression on individual observations. Error bars for hourly means are $\pm 2 \mathrm{SE}$.

suggesting that contributions from such long-residencetime flow paths are minimal. These observations are also consistent with results of a conservative tracer addition to the Ichetucknee River in which over 99\% of the added tracer exited the system within $10 \mathrm{~h}$ (R. Hensley unpubl.).

The simplest line of evidence against the occurrence of significant instantaneous assimilation at $\left[\mathrm{NO}_{3}^{-}\right]_{\max }$ is the close correspondence between $U_{\mathrm{a}-\mathrm{GPP}}$ and $U_{\mathrm{a}-\mathrm{NO}_{3} \text {-pre }}$. While it is possible that the slope near unity between $U_{\text {a-GPP }}$ and $U_{\mathrm{a}-\mathrm{NO}_{3} \text {-pre }}$ reflects fortuitous selection of parameters in the calculation of $U_{\mathrm{a}-\mathrm{GPP}}$, these coefficients are reasonably well constrained. The $\mathrm{C}: \mathrm{N}$ ratio we used $(25: 1)$ is based on measurements of vegetation in Florida springs (Canfield and Hoyer 1988), and is only slightly higher than average $\mathrm{C}: \mathrm{N}$ ratios of benthic algae in other high-light environ- ments (20:1; Hall and Tank 2003). Substituting the values of $r_{\mathrm{a}}(0.5)$ and photosynthetic coefficient (1.0) in Hall and Tank (2003) for those suggested by Webster et al. (2003) (0.3 and 1.2, respectively) would increase $U_{\mathrm{a}-\mathrm{GPP}}$ estimates by only $16.6 \%$. Given higher expected metabolic demands of biomass maintenance in macrophytes, we believe the coefficients used in this study to be more appropriate.

A second observation in support of our assumption is the sustained plateau of $\left[\mathrm{NO}_{3}^{-}\right]$between 01:00 and 05:00 $\mathrm{h}$ during the November-December deployment, which is most easily explained as a complete nighttime cessation of autotrophic assimilation during that period. The close correspondence of $U_{\mathrm{a}-\mathrm{GPP}}$ and $U_{\mathrm{a}-\mathrm{NO}_{3} \text {-pre }}$ during that window of time suggests that our chosen parameters are reasonable. That those parameters would differ significantly during other times of year in such a relatively stable system seems unlikely.

A final line of evidence in support of our assumption of negligible assimilation at $\left[\mathrm{NO}_{3}^{-}\right]_{\max }$ is that the magnitude of day-to-day variation in $\left[\mathrm{NO}_{3}^{-}\right]_{\max }$ is inconsistent with even the most generous assumptions of autotrophic $\mathrm{N}$ demand relative to biomass production. The key point is that if autotrophic assimilation occurs at night, we must assume that daytime assimilation is similarly underestimated by our approach. Because this bias would occur over the entire diel cycle, even small deviations from our assumption of negligible uptake at $\left[\mathrm{NO}_{3}^{-}\right]_{\max }$ would lead to large increases in estimated autotrophic assimilation. For example, if nighttime autotrophic assimilation were sufficient to reduce concentrations by $30 \mu \mathrm{g} \mathrm{NO}_{3}-\mathrm{N} \mathrm{L}^{-1}$ (i.e., if the "true" baseline for estimating assimilation from diel $\mathrm{NO}_{3}^{-}$ variation were $30 \mu \mathrm{g} \mathrm{NO}_{3}-\mathrm{N} \mathrm{L}^{-1}$ greater than the observed $\left[\mathrm{NO}_{3}^{-}\right]_{\max }$ ), autotrophic assimilation during the spring season would more than double the magnitude of $U_{\mathrm{a}-\mathrm{GPP}}$ and $U_{\mathrm{a}-\mathrm{NO}_{3} \text {-pre }}$ determined by our original approaches, suggesting a $\mathrm{C}: \mathrm{N}$ stoichiometry of combined macrophyte and epiphytic algal production of around 12:1. Nighttime assimilation able to account for a reduction of only $15 \mu \mathrm{g}$ $\mathrm{NO}_{3}-\mathrm{N} \mathrm{L}^{-1}$ would imply a doubling of the lower fallseason estimates. We note that day-to-day changes in $\left[\mathrm{NO}_{3}^{-}\right]_{\max }$ were this large on several occasions during our relatively limited period of observation, and they occurred in response to only moderate variation in GPP $( \pm 30 \%$; Fig. 6). For such moderate day-to-day variation in GPP to account for observed variation in $\left[\mathrm{NO}_{3}^{-}\right]_{\max }$ (assuming a linear relationship between GPP and autotrophic assimilation at the subsequent $\left[\mathrm{NO}_{3}^{-}\right]_{\max }$ ) would require nighttime assimilation that could reduce $\left[\mathrm{NO}_{3}^{-}\right]_{\max }$ by $60-80 \mu \mathrm{g} \mathrm{NO}_{3}-$ $\mathrm{N} \mathrm{L}^{-1}$, which in turn would require total assimilation at least 3-4 times greater (implying a $\mathrm{C}: \mathrm{N}$ ratio of $\sim 4: 1$ ) than our higher spring season estimates of $U_{\mathrm{a}-\mathrm{GPP}}$ or $U_{\mathrm{a}-\mathrm{NO}_{3} \text {-pre. }}$ Taken together, these observations support our assumption that autotrophic assimilation does not contribute substantially to observed day-to-day variation in $\left[\mathrm{NO}_{3}^{-}\right]_{\max }$ or the large difference between $\left[\mathrm{NO}_{3}^{-}\right]_{\max }$ and upstream springs inputs.

The second basic assumption of our diel $\mathrm{NO}_{3}^{-}$approach is that other $\mathrm{N}$ species and other $\mathrm{N}$-removal processes are diurnally invariant. Since $\mathrm{NH}_{4}^{+}$is nearly always undetectable in the Ichetucknee River (Heffernan et al. 2010), diel 

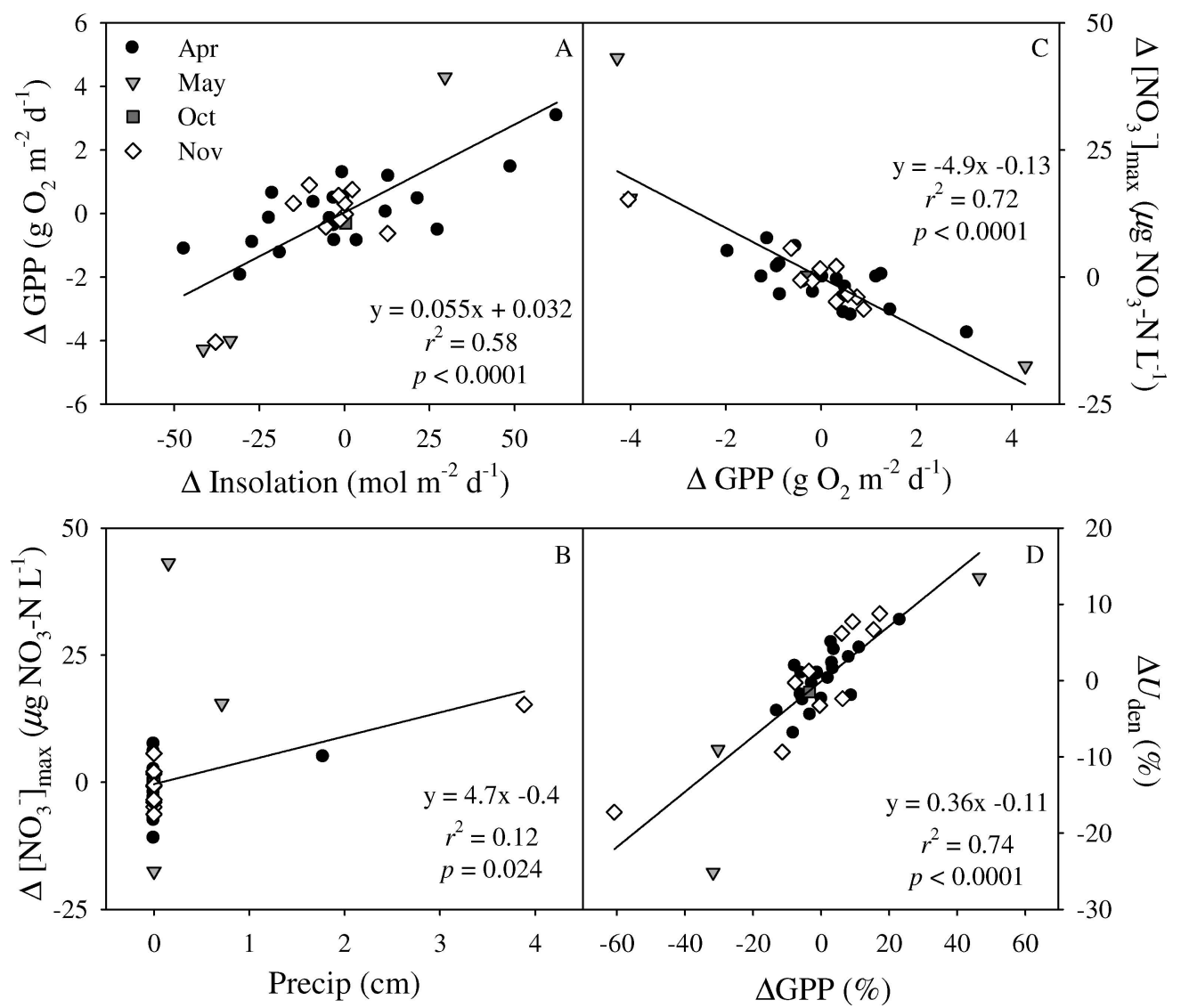

Fig. 6. Drivers of day-to-day variation in the Ichetucknee River, showing relationships between (A) changes in light ( $\Delta$ insolation) and gross primary production ( $\Delta \mathrm{GPP})$, (B) precipitation and $\Delta\left[\mathrm{NO}_{3}^{-}\right]_{\max }$, (C) $\Delta$ GPP and $\Delta\left[\mathrm{NO}_{3}^{-}\right]_{\max }$, and (D) $\Delta$ GPP and $\Delta U_{\text {den }}$ (both expressed as percent change from the previous day). Lines indicate best-fit least-mean-square regression on all data.

variation in $\mathrm{NH}_{4}^{+}$concentration is probably of insufficient magnitude to influence our results substantially. Our observations do suggest that short timescale variation in heterotrophic assimilation and/or denitrification occurs in the Ichetucknee River, but that this variation is principally during nighttime hours. Specifically, if $U_{\text {den }}$ and/or $U_{\text {het }}$ changed continuously during the day, then the relationship between $U_{\mathrm{a}-\mathrm{GPP}}$ and $U_{\mathrm{a}-\mathrm{NO}_{3} \text {-int }}$ would be stronger than that between $U_{\mathrm{a}-\mathrm{GPP}}$ and $U_{\mathrm{a}-\mathrm{NO}_{3} \text {-pre }}$. The fact that we observed the opposite suggests that variation in $U_{\text {den }}$ and/or $U_{\text {het }}$ occurs primarily at night, possibly due to changes in sediment DO gradients (Christensen et al. 1990). Predawn decreases in $\mathrm{NO}_{3}^{-}$during the spring are also consistent with nocturnal variation in denitrification or, less probably, heterotrophic assimilation.

Our study of the Ichetucknee River suggests that diel variation in $\mathrm{NO}_{3}^{-}$can be used to quantify $\mathrm{N}$ assimilation with relatively high precision. While our estimates of GPP and $\mathrm{N}$ assimilation in the Ichetucknee River are high relative to those observed in small streams (Hall et al. 2009), smaller streams with lower specific discharge may exhibit similar magnitudes of $\mathrm{NO}_{3}^{-}$variation despite lower rates of photosynthesis (Roberts and Mulholland 2007). Estimation of autotrophic assimilation from diel $\mathrm{NO}_{3}^{-}$ variation may not be possible where diel variation in denitrification is large (Laursen and Seitzinger 2004; Harrison et al. 2005), where large longitudinal dispersion mutes diel variability, or where human management produces idiosyncratic variation in $\mathrm{NO}_{3}^{-}$inputs (Pellerin et al. 2009). In systems where upstream inputs are less constant than in spring-fed systems like the Ichetucknee River, a two-station method based on diel variation in differences between upstream and downstream sensors may be needed.

Despite potential challenges in less than ideal environments, application of the diel $\mathrm{NO}_{3}^{-}$approach can contribute substantially to our understanding of nutrient dynamics in aquatic ecosystems, particularly in large rivers. Because estimates of autotrophic assimilation are independent of metabolism measurements, comparison of these measurements can be used to identify lags and stoichiometric variation in the relationship between primary production and nutrient assimilation both within and among systems. Extended in situ sensor deployments allow replication of daily rate estimates and, more importantly, evaluation of inter-related dynamics of processes at multiple timescales, including those (e.g., day-to-day changes) that are logistically prohibitive to evaluate via 
solute injections or other approaches. Moreover, estimates of denitrification dynamics from this approach are only influenced by metabolism estimates to the extent that ER and $U_{\text {het }}$ vary over time.

Day-to-day variation: Indirect coupling of photosynthesis and $\mathrm{NO}_{3}^{-}$dynamics via denitrification - Consistent with long-term $\mathrm{N}$ mass balance in the Ichetucknee River (Heffernan et al. 2010), our data indicate that $\mathrm{N}$ removal in this system occurs predominantly via denitrification ( $81 \%$ and $80 \%$ in spring and fall, respectively). Estimates of denitrification per unit area are high compared to most streams and rivers (Pina-Ochoa and Alvarez-Cobelas 2006; Mulholland et al. 2008), but they are similar to openchannel estimates of denitrification in larger, N-enriched rivers (Laursen and Seitzinger 2002; McCutchan et al. 2003). These high rates of denitrification may reflect greater availability of labile $\mathrm{OM}$ in more productive, larger rivers (Heffernan et al. 2010). Seasonal variation in denitrification, which occurs despite relatively stable temperatures in the Ichetucknee River, is also consistent with the dependence of denitrification on seasonally varying autochthonous production. In the present study, the relationship between day-to-day variation in GPP and changes in $\left[\mathrm{NO}_{3}^{-}\right]_{\max }$ indicates that such coupling may be manifest at relatively short temporal scales.

Several mechanisms could, in principle, produce the negative relationships between interday variation in productivity and subsequent changes in $\left[\mathrm{NO}_{3}^{-}\right]_{\max }$ in the Ichetucknee River (Fig. 6C). One potential explanation is that our assumption of constant inputs is invalid. Declines in GPP are associated with high cloud cover and, potentially, flushing events that increase $\mathrm{N}$ delivery to springs during large rain events $(>20 \mathrm{~cm}$; Martin and Gordon 2000). However, the magnitude of rain events during our study was small, with only two events $>$ $1.5 \mathrm{~cm}$, and the largest changes in $\left[\mathrm{NO}_{3}^{-}\right]_{\max }$ occurred following the smallest rain event $(<0.15 \mathrm{~cm})$. Moreover, the relationship between spring discharge and rainfall occurs with long $(\sim 100 \mathrm{~d})$ lags, and associated changes in spring discharge chemistry have even longer $(\sim 6-$ 18 month) lags (Heffernan et al. 2010). Finally, since the relationship between $\Delta$ GPP and $\Delta\left[\mathrm{NO}_{3}^{-}\right]_{\max }$ remains clear, even when the $2 \mathrm{~d}$ following rain events are excluded, we conclude that changes in $\left[\mathrm{NO}_{3}^{-}\right]_{\max }$ during rain events are driven by variation in GPP rather than changes in $\mathrm{NO}_{3}^{-}$inputs.

In light of evidence that nighttime autotrophic assimilation is negligible, coupling of GPP and $\left[\mathrm{NO}_{3}^{-}\right]_{\max }$ must result from variation in either $U_{\text {het }}$ or $U_{\text {den }}$. Day-to-day changes in $\left[\mathrm{NO}_{3}^{-}\right]_{\max }$ ranged from -17 to $+45 \mu \mathrm{g} \mathrm{NO}{ }_{3}-\mathrm{N}$ $\mathrm{L}^{-1}$, which equates to variation in nighttime $\mathrm{N}$ removal between 66 and $-166 \mathrm{mg} \mathrm{N} \mathrm{m}^{-2} \mathrm{~d}^{-1}$. This day-to-day variation is several times greater than our mean estimates of $U_{\text {het }}$, but it represents interday variation in $U_{\text {den }}$ of only $13 \%$ to $-25 \%$. Based on the small magnitude of $U_{\text {het }}$ and minimal interday variation in ER, we conclude that interday variation in $\left[\mathrm{NO}_{3}^{-}\right]_{\max }$ results from a coupling of recent autotrophic production and dissimilatory $\mathrm{NO}_{3}^{-}$ removal. Low $\left[\mathrm{NH}_{4}^{+}\right]$suggests that $\mathrm{N}_{2}$ production, rather than dissimilatory nitrate reduction to ammonium (DNRA), is the ultimate mechanism of $\mathrm{NO}_{3}^{-}$removal.

Because the conditions on which denitrification depends (high $\mathrm{NO}_{3}^{-}$, labile organic $\mathrm{C}$, anoxia) are all influenced by the activities of autotrophs, several mechanisms could produce relationships between $\Delta \mathrm{GPP}$ and $\Delta U_{\mathrm{den}}$, but not all are consistent with the positive relationship we observed in the Ichetucknee River. For example, if day-to-day changes in $U_{\text {den }}$ were driven by variation in $\mathrm{DO}$, as has been observed in some streams (Christensen et al. 1990; Harrison et al. 2005), we would expect increased $U_{\text {den }}$ following days of low productivity, rather than the observed positive relationship. Alleviation of $\mathrm{NO}_{3}^{-}$limitation of denitrification via reduced assimilation on days with lowered GPP is unlikely given high concentrations and fluxes in the Ichetucknee River, and it would not produce changes in denitrification of greater magnitude than changes in assimilation. Instead, observations are consistent with exacerbation and alleviation of $\mathrm{C}$ limitation of denitrification, presumably due to changes in exudation by primary producers, following days of low and high productivity, respectively. The slope of the relationship between $\Delta$ GPP and $\Delta U_{\text {den }}$ (expressed on a percent basis; Fig. 6D) suggests that $\sim 35 \%$ of denitrification may be driven by the previous day's photosynthesis.

Large-river $N$ dynamics, high-resolution nutrient chemistry, and coupled biogeochemical cycles-The short-term coupling of GPP and denitrification in the Ichetucknee River supports the broader hypothesis that riverine $\mathrm{N}$ removal via denitrification increases with autochthonous productivity (Heffernan et al. 2010). This dependence on autochthonous production may be markedly weaker where and when heterotrophic respiration is predominantly fueled by allochthonous OM, as is the case in many small streams. Indeed, across small streams in various biomes and land uses, ecosystem respiration is a better predictor of denitrification than is GPP; however, productive small streams also have relatively high rates of ecosystem respiration, and thus somewhat higher denitrification (Mulholland et al. 2009). Since large rivers are, in general, more productive and less dependent on allochthonous OM than headwater streams (Vannote et al. 1980), we suggest that denitrification is likely to become more dependent on autochthonous production of labile $\mathrm{OM}$ with increasing channel size. Where longitudinal patterns of autochthonous and allochthonous OM inputs differ (Wiley et al. 1990), so will the dependence of denitrification on in situ production. Regardless of its spatial and temporal distribution, primary production is likely to exert a strong influence on riverine $\mathrm{N}$ dynamics, both directly via assimilation and indirectly via effects on heterotrophic activity (i.e., uptake, DNRA, and denitrification). Improving our understanding of these relationships will require the integration of current tools and continued development of new approaches to $\mathrm{N}$ dynamics in large rivers.

High-frequency measurements of nutrient chemistry obtained from in situ sensors provide both a motivation to develop and a means to evaluate increasingly integrative models of biogeochemical and hydrologic processes in both 
terrestrial and aquatic systems (Kirchner et al. 2004). The value of these measurements will be maximized when collected in combination with other measurements (e.g., open-channel metabolism and denitrification, chamber and sediment core experiments) that can be used to test mechanistic hypotheses and strengthen inferences derived from high-frequency measurements. Conversely, highresolution measurements can be used to evaluate ecosystem-scale predictions that follow from mechanistic models and experiments. Such an integrated approach will be necessary to develop a process-specific understanding of large river $\mathrm{N}$ dynamics. Moreover, high-frequency in situ measurements of nutrient chemistry in aquatic environments where the aqueous medium and action of flow serve to integrate spatially heterogeneous processes will provide a useful approach to the study of more general models of coupled biogeochemical cycles that may inform studies of terrestrial systems where similar measurements are not presently possible.

\section{Acknowledgments}

We thank Chad Foster and Larry Korhnak for assistance with collection and analysis of water samples and maintenance of sensors in the field. Ray Thomas provided critical assistance with upkeep and troubleshooting of in situ sensors. Maury Valett and two anonymous reviewers provided helpful comments, which helped to clarify approaches to data acquisition and analysis. This study was supported by grants from the National Science Foundation (Division of Earth Sciences 0609968), the St. Johns Water Management District (contract 25140), and by the Carl Swisher Foundation via the University of Florida (UF) Water Institute. This paper is a contribution to the research program of the UF Water Institute.

\section{References}

Canfield, D. E., And M. V. Hoyer. 1988. Influence of nutrient enrichment and light availability on the abundance of aquatic macrophytes in Florida streams. Can. J. Fish.Aquat. Sci. 45: 1467-1472.

Cebrian, J., and C. M. Duarte. 1995. Plant growth-rate dependence of detrital carbon storage in ecosystems. Science 268: $1606-1608$.

Chapra, S. C., And D. M. Di Toro. 1991. Delta method for estimating primary production, respiration, and reaeration in streams. J. Environ. Eng. 117: 640-655.

Christensen, P. B., L. P. Nielsen, J. Sorensen, and N. P. Revsbech. 1990. Denitrification in nitrate-rich streams: Diurnal and seasonal variation related to benthic oxygen metabolism Limnol. Oceanogr. 35: 640-651.

Dodds, W. K., AND others. 2008. Nitrogen cycling and metabolism in the thalweg of a prairie river. J. Geophys. Res 113: G04029, doi:10.1029/2008JG000696.

Fellows, C. S., H. M. Valett, C. N. Dahm, P. J. Mulholland, AND S. A. Thomas. 2006. Coupling nutrient uptake and energy flow in headwater streams. Ecosystems 9: 788-804.

Grimm, N. B. 1987. Nitrogen dynamics during succession in a desert stream. Ecology 68: 1157-1170.

Hall, R. O., JR., And J. L. TANK. 2003. Ecosystem metabolism controls nitrogen uptake in streams in Grand Teton National Park, Wyoming. Limnol. Oceanogr. 48: 1120-1128.

— AND OTHERs. 2009. Nitrate removal in stream ecosystems measured by ${ }^{15} \mathrm{~N}$ addition experiments: Total uptake. Limnol. Oceanogr. 54: 653-665.
Hamilton, E. W., And D. A. Frank. 2001. Can plants stimulate soil microbes and their own nutrient supply? Evidence from a grazing tolerant grass. Ecology 82: 2397-2402.

Harrison, J. A., P. A. Matson, And S. E. Fendorf. 2005. Effects of a diel oxygen cycle on nitrogen transformations and greenhouse gas emissions in a eutrophied subtropical stream. Aquat. Sci. 67: 308-315.

HefFernan, J. B., AND others. 2010. Hydrologic and biotic influences on nitrate removal in a subtropical spring-fed river. Limnol. Oceanogr. 55: 249-263.

Hoellein, T. J., J. L. Tank, E. J. Rosi-Marshall, S. A. Entrekin, AND G. A. Lamberti. 2007. Controls on spatial and temporal variation of nutrient uptake in three Michigan headwater streams. Limnol. Oceanogr. 52: 1964-1977.

Holmes, R. M., J. B. Jones, S. G. Fisher, and N. B. Grimm. 1996. Denitrification in a nitrogen-limited stream ecosystem. Biogeochemistry 33: 125-146.

Johnson, K. S., L. J. Coletti, and F. P. Chavez. 2006. Diel nitrate cycles observed with in situ sensors predict monthly and annual new production. Deep-Sea Res. I 53: 561-573.

Kirchner, J. W., X. H. Feng, C. NeAl, and A. J. Robson. 2004. The fine structure of water-quality dynamics: The (highfrequency) wave of the future. Hydrol. Proc. 18: 1353-1359.

Knops, J. M. H., K. L. Bradley, and D. A. Wedin. 2002. Mechanisms of plant species impacts on ecosystem nitrogen cycling. Ecol. Lett. 5: 454- 466.

Kurz, R. C., D. Woithe, S. K. Notestein, T. K. Frazer, J. A. Hale, and S. R. Keller. 2004. Mapping and monitoring submerged aquatic vegetation in Ichetucknee springs. Report for Contract No. 02/03-180. Suwannee River Water Management District, Live Oak, FL.

Laursen, A. E., and S. P. Seitzinger. 2002. Measurement of denitrification in rivers: An integrated, whole reach approach. Hydrobiologia 485: 67-81.

— AND - 2004. Diurnal patterns of denitrification, oxygen consumption and nitrous oxide production in rivers measured at the whole-reach scale. Freshw. Biol. 49: 14481458.

Martin, J. B., AND S. L. Gordon. 2000. Surface and ground water mixing, flow paths, and temporal variations in chemical compositions of karst springs, p. 65-92. In I. D. Sasowsky and C. Wicks [eds.], Groundwater flow and contaminant transport in carbonate aquifers. A. A. Balkema.

McCutchan, J. H., J. F. Saunders, A. L. Pribyl, and W. M. LEWIS. 2003. Open-channel estimation of denitrification. Limnol. Oceanogr. Meth. 1: 74-81.

Mulholland, P. J., S. A. Thomas, H. M. Valett, J. R. Webster, AND J. Beaulieu. 2006. Effects of light on $\mathrm{NO}^{-}{ }_{3}$ uptake in small forested streams: Diurnal and day-to-day variations. J. N. Amer. Benthol. Soc. 25: 583-595.

, AND OTHERS. 2008. Stream denitrification across biomes and its response to anthropogenic nitrate loading. Nature 452: 202-205, doi:10.1038/nature06686.

— AND OTHERS. 2009. Nitrate removal in stream ecosystems measured by ${ }^{15} \mathrm{~N}$ addition experiments: Denitrification. Limnol. Oceanogr. 54: 666-680.

Odum, H. T. 1957. Trophic structure and productivity of Silver Springs, Florida. Ecol. Monogr. 27: 55-112.

Owens, M. 1974. Measurements on non-isolated natural communities in running waters, p. 111-119. In R. A. Vollenweider [ed.], A manual on methods for measuring primary production in aquatic environments. Blackwell.

Pellerin, B. A., And others. 2009. Assessing the sources and magnitude of diurnal nitrate variability in the San Joaquin River (California) with an in situ optical nitrate sensor and dual nitrate isotopes. Freshw. Biol. 54: 376-387. 
Picek, T., H. Cizkova, and J. Dusek. 2007. Greenhouse gas emissions from a constructed wetland-plants as important sources of carbon. Ecol. Eng. 31: 98-106.

Pina-Ochoa, E., and M. Alvarez-Cobelas. 2006. Denitrification in aquatic environments: A cross-system analysis. Biogeochemistry 81: 111-130.

Roberts, B. J., and P. J. Mulholland. 2007. In-stream biotic control on nutrient biogeochemistry in a forested stream, West Fork of Walker Branch. J. Geophys. Res 112: G04002, doi:10.1029/2007JG000422.

Simal, J., M. A. Lage, And I. Iglesias. 1985. Second derivative ultraviolet spectroscopy and sulfamic acid method for determination of nitrates in water. J. Anal. Chem. 68: 962-964.

Sterner, R. W., And J. J. Elser. 2002. Ecological stoichiometry: The biology of elements from molecules to the biosphere. Princeton Univ. Press.

Tank, J. L., E. J. Rosi-Marshall, M. A. Baker, and R. O. Hall. 2008. Are rivers just big streams? A pulse method to quantify nitrogen demand in a large river. Ecology 89: 2935-2945.

Templer, P. H., W. L. Silver, J. Pett-Ridge, K. M. Deangelis, AND M. K. Firestone. 2008. Plant and microbial controls on nitrogen retention and loss in a humid tropical forest. Ecology 89: $3030-3040$.

VAlett, H. M., AND others. 2008. Endogenous and exogenous control of ecosystem function: $\mathrm{N}$ cycling in headwater streams. Ecology 89: 3515-3527.
VAnce, E. D., And F. S. Chapin. 2001. Substrate limitations to microbial activity in taiga forest floors. Soil Biol. Biochem. 33: $173-188$.

Vannote, R. L., G. W. Minshall, K. W. Cummins, J. R. Sedell, AND C. E. Cushing. 1980. The river continuum concept. Can. J. Fish. Aquat. Sci. 37: 130-137.

von Schiller, D., E. Martí, J. L. Riera, M. Ribot, A. Argerich, P. Fonollà, AND F. SABATER. 2008. Inter-annual, annual, and seasonal variation of $\mathrm{P}$ and $\mathrm{N}$ retention in a perennial and an intermittent stream. Ecosystems 11: 670-687.

Webster, J. R., AND others. 2003. Factors affecting ammonium uptake in streams - an inter-biome perspective. Freshwa. Biol. 48: 1329-1352.

Wiley, M. J., L. L. Osborne, and R. W. Larimore. 1990 Longitudinal structure of an agricultural prairie river system and its relationship to current stream ecosystem theory. Can. J. Fish. Aquat. Sci. 47: 373-384.

Wollheim, W. M., C. J. Voosmarty, B. J. Peterson, S. P. Seitzinger, And C. S. Hopkinson. 2006. Relationship between river size and nutrient removal. Geophys. Res. Lett 33: L06410, doi:10.1029/2006GL025845.

Associate editor: H. Maurice Valett

Received: 27 August 2009

Accepted: 25 November 2009

Amended: 07 December 2009 